\section{Quality control}

Vera Rich writes on the reorganisation of higher degrees in the Soviet Union

ThE Soviet media are at present conducting a major campaign eulogising Soviet achievements, as part of the build-up to the forthcoming 60th anniversary of the October Revolution. The achievements of Soviet science feature conspicuously in this campaign. In one field, however, there is little cause for rejoicing, and the press notices strike a critical note-the training of the next generation of scientists and the awarding of higher degrees.

In the Soviet Union, the degrees of Candidate (roughly equivalent to a PhD) and Doctor of Science are awarded not by the universities, but by a special body, the Higher Qualifications Commission (Vysshaya Attestatsionnaya Kommissiya, VAK) of the Ministry of Higher Education. At the beginning of 1976, new regulations for higher degrees came into force, setting new, higher standards and reorganising the structure of VAK. In its new form, VAK consists of a 'Plenum', a 'Presidium' and a 'College', with 34 'councils of experts' dealing with the principal lines of research, and 500 'specialist councils' for assessing degree theses, 150 of these councils being entitled to deal with doctorate theses.

Under the new regulations, a higher standard is demanded, both in the theses themselves and also in the official opponents against whom the theses must be defended. Postulants for a higher degree have, in addition, to fulfil certain non-academic requirements; according to Professor V. G. KirillovUgryumov, the Chairman of VAK, they are expected to "combine a profound professional knowledge with a mastery of Marxist-Leninist theory and with the convictions of an active builder of communist society."

In spite of this emphasis on partiinost' (Party-mindedness), the changes were primarily intended to improve the standards of scientific manpower. The first year's work of the reorganised VAK has, however, failed to effect this improvement, and the overall picture suggests incompetence and inadequacy.

According to Pravda, a number of the degree councils have not been observing the proper procedure for the defence of theses and have been deliberately lowering their standards for reasons ranging from "bonds of friendship" to the "exploitation of official status" by the postulant. Twenty-one degree councils have been suspended as a result of such infringements. Nevertheless, during the year, almost $20 \%$ of doctoral theses were rejected by VAK.

Theses appear to be of a low standard because more than half the postulants come from industry, having carried out their research while working in jobs which may not necessarily be closely related to their academic work. This is a somewhat delicate matter to broach in the media; Soviet policy constantly urges a closer contact between research and industry, and even so eminent a body as the Siberian Branch of the Academy of Sciences of the USSR was recently censured for slackness in establishing and maintaining such contacts.

However, Moscow radio recently hinted at some of the difficulties facing the young graduate who goes straight into production and attempts, while working, to obtain a higher degree.
Those who embark on such a course, suggested the commentator, should be "surrounded by care and attention". In plants where this had been done, working scientists had obtained degrees not only at the Candidate level but even at the Doctor level. Directors who failed to cherish in this way their ambitious young scientists "display shortsightedness and lack of foresight". The difficulties of combining research with a job, even a job in one's chosen field, were considerable, and accordingly, while in no way overtly criticising official policy, the commentator urged that special attention should be paid to ensuring that more young graduates gain their research experience in the most authoritative establishments.

The current Five-Year plan is aimed at increasing efficiency and quality in all sectors of production, including the higher education 'industry'. The reorganisation of VAK was but one aspect of this drive towards quality. The first results of the new system show that it is not easy to achieve higher standards simply by legislation.

\title{
More give, more take
}

DR Mikhail Shtern was unexpectedly released last week from the labour camp where he was serving an eight-year sentence for allegedly accepting bribes. The official TASS statement on his release maintained that the sentence was "correct", but claimed that acting on considerations of socialist humanity, and in view of Dr Shtern's poor state of health, the Supreme Court of the Ukrainian SSR had decided to reduce the sentence to two years and nine-months--the term already served.

After his release, Dr Shtern told foreign reporters that he was "absolutely not guilty of anything", and that the accusations against him were made in reprisal for his sons' application to go to Israel. Dr Shtern's release followed a worldwide protest campaign which involved fifty Nobel Prize winners. A special tribunal to examine the Shtern case was scheduled to open in Amsterdam this week.

Dr Shtern's release, however, does not appear to augur a relaxation of pressure on the refusniks. In Moscow, Yosif Begun, an electrical engineer, is in prison awaiting charges of "parasitism", that is, being without visible means of support-a charge which has not been brought against any refusnik for some time. On 15 March, the day after Shtern's release, Anatolii Shcharanskii, the mathematician who has acted as press agent for the Azbel' Seminar and is closely associated with the Moscow 'Helsinki monitoring group', was arrested while actually in the company of two Western journalists who were interviewing him about the Shtern case. Shcharanskii's family has been told that he may be accused of "crimes against the State", an accusation which could lead to a show trial.

Jewish activists in Moscow see the arrest of Shcharanskii as part of a growing campaign of repression against the refusniks. Although there have been recent attacks in the media on other dissidents too, the campaign against the Jews who simply wish to leave the Soviet Union is far more aggressive than that against the Russians, Ukrainians, Lithuanians and others who also urge change.

The anti-refusnik campaign has been particularly directed against the scientists and academics. Searches of unprecedented severity have taken place at the homes of several of them, resulting in the destruction of their books and the confiscation of all papers. At the time of his arrest Shcharanskii, together with Professor Aleksandr Lerner, a cyberneticist, and Vladimir Slepak, an engineer, were attempting to bring a libel suit against the government newspaper Izvestiya, which had accused them of spying for the CIA.

Vera Rich 